\title{
Technological Innovation in Small Business: A Study on the Three Recent Baldrige Awards' SMEs Recipients (2017-2019)
}

\author{
Budi Harsanto $^{1 *}$ \\ ${ }^{1}$ Universitas Padjadjaran, Bandung 40132, Indonesia \\ *Corresponding author. Email: budi.harsanto@unpad.ac.id
}

\begin{abstract}
This paper aims to understand the technological innovation in the recent winners of the latest Baldrige Awards' SMEs recipients 2017-2019. The Baldrige Award is the highest award for performance excellence in various business categories in the US, including small business or small-medium enterprises (SMEs). The method used is documentary analysis from their Baldrige application summary and is supported by other publicly available sources. The analysis shows that all recipients have in common in terms of depth of expertise in their respective fields, accompanied by an organization that encourages innovation at various managerial levels. This paper contributes to the literature by providing current insights on how SMEs performed their technological innovation. Even though it is carried out in an advanced economy context, this study may also be useful for small businesses in different contexts.
\end{abstract}

Keywords: Technological innovation, small business, SMEs, Malcolm Baldrige National Quality Award (MBNQA) Baldrige award

\section{INTRODUCTION}

Rapid technological changes and global competition encourage companies to perform their business excellently to produce high-quality products/ services and low production costs [1], [2]. Many countries provide assessments and awards for best practices to promote business excellence. Among the three well-known business excellence awards are the Malcolm Baldrige National Quality Award (MBNQA) in the US, the European Quality Award in Europe, and the Deming Prize in Japan [3]. These awards are recognition for best practices at the firm-level that are systematically documented in the firm's applications following certain standards.

MBNQA, or known as Baldrige Award, was first introduced in 1987, covering manufacturing, service, and small business categories. Currently, this category has expanded with the addition of education, healthcare, and non-profit categories [4]. There are seven critical aspects assessed in the MBNQA, namely leadership; strategy; customers; measurement, analysis, and knowledge management; workforce; operations; and results [5]. Apart from these critical aspects, there are quite some core concepts underlying MBNQA, including managing for innovation.

Managing for innovation in MBNQA means meaningful changes to improve diverse business aspects ranging from business models, processes, programs to products and services [5]. Among the innovation typologies popular in the literature is the technological-organizational typology
[6]. Technological innovation is concerned with implementing ideas into a firm's operations or commercialization into products and services, while organizational innovation relates to an improvement in management practices [7]. The two are related to each other in the firm.

The purpose of this paper is to understand the technological innovation in the latest winner of MBNQA in the small business category. In contrast to recent research investigating MBNQA winners in the context of healthcare, this research is conducted in the context of small business [8]. This study contributes to the literature by providing preliminary insights to both small business practitioners and researchers in this field regarding technological innovation in small businesses. This paper is structured as follows. The next section described a review of the literature on technological innovation. The methodology is explained in the third section. Results and discussion is presented in the fourth section. The conclusion is provided in the last section.

\section{TECHNOLOGICAL INNOVATION}

Technological innovation is defined as "the implementation of an idea for a new product or a new service or the introduction of new elements in an organization's production process or service operation." [9]. Technological innovation is one of two types of innovation in a technological-organizational typology that is popular in 
research on innovation [10]. In the classic definition, technological innovation focuses on implementing ideas in the form of processes or end results in the form of products and/or services. Organizational innovation focuses on improvement in management practices to help companies achieve their organizational goals [7].

In organizations, technological innovation is vital because it is the key to survival and growth [11]. Furthermore, technological innovation is also playing a major role in shaping the structure of an industry and in global trade [11]. Technological innovation is a function of three factors, including the internal characteristics of the firm, the characteristics of the firm's environment, and the flows between the firm and its environment [11]. In the sociotechnical system theory, technological innovation requires organizational innovation as a necessary precondition [12], [13]. [10,11]. Therefore, technological and organizational innovation are two types of innovation that are closely related.

The application of technological innovation varies from one organization to another. An example of technological innovation is creating or significantly improving a new product, improving an existing product, introducing information and communication technology (ICT) for the production process or automation in operations [14], [15]. For organizational innovation, the application in the firm, for example, the introduction of a new department or team, development of training programs for human resources, the introduction of pricing or distribution methods, or exploration of new markets [14].

Technological innovation in SMEs is challenging because it requires a long-term commitment to developing specific knowledge [16], [17]. This certainly requires adequate resources and commitment. SMEs are generally known to be limited in terms of resources when compared to large corporations [18]-[20]. This, of course, affects SMEs' various activities, including innovation [21]. However, besides constraints, previous researchers highlighted the positive side of SMEs, for example, in the form of a lean structure, agile bureaucracy, exceptional operational expertise, and commercializing disruptive technology [22].

\section{METHODOLOGY}

This paper uses a qualitative approach using document analysis. This approach is chosen because of its suitability with this study that is a qualitative case study to analyze technological innovation in the three most recent MBNQA winners from the small business category. Document analysis is a systematic procedure for reviewing and evaluating documents [23]. Document analysis is a systematic procedure for reviewing and evaluating documents [23].

Document analysis is useful for exploring the meaning and gaining insight into empirical knowledge [24]. The documents analyzed were text and images which were produced without the intervention of the researcher [23]. In this study, the main document analyzed is the Baldrige Award Application Summary obtained from the US Department of Commerce's National Institute of Standards and Technology website (www.nist.gov). In addition, other documents analyzed are the website of the winning company and other relevant documents that are publicly available.

The data is then processed by coding the document, which is related to innovation, especially technological innovation. The analysis is carried out by identifying the firm's technological innovation as well as five key management innovation dimensions, including strategy, process, organization, linkages, and learning [25]. Whenever possible, direct excerpts from the application summary are included in the results and discussion. The analysis process is assisted by NVivo 12 qualitative software.

\section{RESULTS AND DISCUSSIONS}

In the 2017-2019 period, there were three Baldrige Award recipients from the small business category, namely Bristol Tennessee Essential Services (BTES), Stellar Solutions (SS), and Integrated Project Management Company, Inc. (IPMC).

Table 1 The three firms' brief profile and technological innovation example

\begin{tabular}{|c|c|c|c|}
\hline & $\begin{array}{l}\text { Firm 1: } \\
\text { BTES }\end{array}$ & $\begin{array}{l}\text { Firm 2: } \\
\quad \text { SS }\end{array}$ & $\begin{array}{l}\text { Firm 3: } \\
\text { IPMC }\end{array}$ \\
\hline Year establishment & 1945 & 1995 & 1988 \\
\hline Year receiving award & 2017 & 2017 & 2018 \\
\hline Business field & $\begin{array}{l}\text { Electricity and fiber services } \\
\text { utility }\end{array}$ & Aerospace support system & Project management consulting \\
\hline Employee number & 68 & 175 & 182 \\
\hline Website & btes.net/ & $\underline{\text { stellarsolutions.com/ }}$ & ipmcinc.com/ \\
\hline $\begin{array}{l}\text { Technological } \\
\text { innovation example }\end{array}$ & $\begin{array}{l}\text { Combination electric and } \\
\text { fiber optic system; The use of } \\
\text { fiber optic to monitor water } \\
\text { heater usage; Green initiatives } \\
\text { through electric vehicle and } \\
\text { charging stations. }\end{array}$ & $\begin{array}{l}\text { Systems engineering for space } \\
\text { and ground systems; Speed up } \\
\text { the design of client's systems } \\
\text { and projects; Continuity, } \\
\text { resiliency \& cyber } \\
\text { engineering. }\end{array}$ & $\begin{array}{l}\text { Smooth integration new } \\
\text { product rollout for pharma } \\
\text { company; Optimization of } \\
\text { project portfolio management } \\
\text { for surgical device launching. }\end{array}$ \\
\hline
\end{tabular}

Source: data processed 
BTES and SS received the award in 2017, IPMC received it in 2018, while in 2019, there were no awards given for the small business category. The brief profile regarding the three small businesses is shown in table 1 .

The results of the analysis of the innovation management activities for each firm show that these firms are able to deliver sophisticated technological innovation. A detailed analysis of key innovation management and direct excerpts from the document is shown in Table 2 .

The first element in innovation management is strategy. Strategically, the data shows that these three firms have been able to develop a clear distinctive competence as their competitive edge. For example, BTES is able to integrate two different but interconnected technologies (electric and fiber optic) for effectiveness and efficiency in delivering their services to consumers. SS has an innovative strategy by carefully choosing their project in the specific industry, aerospace, which is the realization of the founder's vision. This firm has able to deliver exceptional customer satisfaction to a $100 \%$ level during the period 2013-2016 [26]. In line with it, IPMC is known as the first firm that has dedicated itself to assisting clients in carrying out professional project management. From this analysis, it can be seen that differentiation is the main strategy of these firms.

The second element of innovation management analyzed is the innovation process. These three firms have a strong mechanism for the development of innovation within the firm. The strength of BTES in the innovation process is clarity, while SS and IPMS are in providing a conducive atmosphere to the development of ideas to the realization. BTES measures and communicates data through OFI (opportunity for improvement), which is claimed to be the most rigorous mechanism in the industry that can be found [27] [28]. SS has a mechanism for stimulating innovation by involving all employees in SPP (Stellar's Strategic Planning Process) to encourage innovative ideas. Senior management involvement in the innovation process is practiced by IPMC to encourage employees' intelligent risktaking.

The third element analyzed is innovation organization. As the award is for the small business category, these three firms are small in size characterized by flat organizations that help to foster innovation within the firms. For example, IPMC has a support team to help generate and substantiate ideas to the realization [29] [30]. With a flat organization structure, the involvement of all employees is possible as carried out by SS. All employees are involved in identifying and whenever feasible to execute various improvements in their business, including identifying new areas of business. IPMC in 2016 introduced a special support team to formally generates innovation to substitute fresh ideas within the firm.

The fourth element of innovation management analyzed is innovation linkage. BTES, SS, and IPMC have strong linkages with their primary stakeholders, especially suppliers and customers. BTES maintains close relationships with key suppliers in order to provide reliable and safe service to their customers as well as deliver a costeffective service. This is done through regular conference meetings with their suppliers so that the dynamics supplierfirm information can be updated quickly and accurately. SS emphasizes a long-term orientation in building relationships with their suppliers so as to provide a high level of confidence for the firm to achieve its strategic and operational performance. IPMC highlighted personal touch from top to bottom of the firm to maintain and develop healthy relationships with their customers. From the analysis, it can be seen that both BTES and SS maintain close relationships with their long-term suppliers, while IPMC emphasizes nurture relationships with key customers. The last aspect of innovation analyzed is learning. Learning is evidenced strongly in all firms through a mechanism to review completed projects for improvement in the future as well as special training that focuses on innovation [27], [29], [31]. BTES has a learning mechanism through periodic reviews of their projects, both small and large, to be able to find better ways to execute their projects in the future. SS has a special training program on innovation for their new employees, in addition to the other types of training they already have. This gives a clear message from the beginning to new employees that innovation is a very important part of the firm. IPMC introduces a learning mechanism through training to deliver innovative solutions for customers through job shadowing and also work collaboration on projects to teach new consulting skills for them.

\section{CONCLUSION}

Technological innovation in the three small businesses analyzed is a result of excellent technical expertise along with effective innovation management from each of these companies. This study certainly has several limitations. The firms studied were small businesses located in the advanced economy context, so its applicability may be limited to that context. However, the insights from this study may also be useful for small businesses in emerging economies' context considering the similarity in size of their organizations. Another limitation is that the number of studies studied is limited to three SMEs. The room for improvement and development of this paper is to involve more samples in the longer MBNQA period and a more in-depth analysis of the evidence from richer sources to strengthen the results of the analysis. As this study focuses on technological innovation, future research may also investigate organizational innovation or the linkage between technological innovation and recently developed innovation concepts such as sustainability-oriented innovation [32]-[35]. 
Table 2 Key innovation management and direct excerpts from the document

\begin{tabular}{|c|c|c|c|}
\hline & $\begin{array}{c}\text { Firm 1: } \\
\text { BTES }\end{array}$ & $\begin{array}{c}\text { Firm 2: } \\
\text { SS }\end{array}$ & $\begin{array}{l}\text { Firm 3: } \\
\text { IPMC }\end{array}$ \\
\hline Strategy & $\begin{array}{l}\text { Integration electric and fiber } \\
\text { optic as distinctive } \\
\text { competence. } \\
\text { "The combination of our } \\
\text { electric and fiber optic system } \\
\text { is unique. BTES uses our fiber } \\
\text { optic system to integrate } \\
\text { several innovative systems to } \\
\text { ensure our electric services } \\
\text { are more effective and } \\
\text { efficient. This is an innovative, } \\
\text { cutting-edge approach..." }\end{array}$ & $\begin{array}{l}\text { Only do high impact project } \\
\text { in the aerospace industry. } \\
\text { "The founder had the vision } \\
\text { to create a company that } \\
\text { tackles only high impact } \\
\text { projects and is not driven by } \\
\text { growth or size. The } \\
\text { company's vision, from its } \\
\text { inception, has been to align } \\
\text { employee dream jobs with } \\
\text { customers' critical needs." }\end{array}$ & $\begin{array}{l}\text { First firm in the USE } \\
\text { dedicated to professional } \\
\text { project management. } \\
\text { "Recognizing a pressing } \\
\text { need across industries for } \\
\text { excellence in project } \\
\text { execution, C. Richard (Rich) } \\
\text { Panico founded IPM in } \\
\text { 1988, making it the first } \\
\text { company in the U.S. } \\
\text { dedicated to professional } \\
\text { Project Management" }\end{array}$ \\
\hline Process & $\begin{array}{l}\text { A clear innovative process. } \\
\text { "Our innovative process for } \\
\text { measuring and analyzing } \\
\text { customer communication data } \\
\text { through our OFIs and } \\
\text { positives is the most detailed } \\
\text { and rigorous method that we } \\
\text { can find." }\end{array}$ & $\begin{array}{l}\text { Mechanism to encourage } \\
\text { innovative ideas. } \\
\text { "strategic development } \\
\text { process stimulates and } \\
\text { incorporates innovation by } \\
\text { involving all employees in } \\
\text { the SPP and encouraging } \\
\text { new and innovative ideas.." }\end{array}$ & $\begin{array}{l}\text { A conducive process for } \\
\text { innovation. } \\
\text { "The innovation } \\
\text { management process begins } \\
\text { with senior leadership } \\
\text { creating an environment for } \\
\text { innovation and intelligent } \\
\text { risk taking." }\end{array}$ \\
\hline Organization & $\begin{array}{l}\text { Flat organization structure to } \\
\text { help innovation happen. } \\
\text { "Through open } \\
\text { communication and the } \\
\text { flatness of our organization, } \\
\text { employees are encouraged to } \\
\text { share their ideas and } \\
\text { innovations." }\end{array}$ & $\begin{array}{l}\text { Employee engagement for } \\
\text { innovation. } \\
\text { “.. an environment for } \\
\text { innovation and intelligent } \\
\text { risk taking by engaging all } \\
\text { employees in the SPP and } \\
\text { recognizing employees for } \\
\text { identifying and executing } \\
\text { new areas of business.” }\end{array}$ & $\begin{array}{l}\text { Introduction support team to } \\
\text { generate innovation. } \\
\text { "Created in } 2016 . . . \\
\text { highlighting the need to } \\
\text { foster more innovation, } \\
\text { Greenhouse is IPM's } \\
\text { innovation support team that } \\
\text { employs a formal process to } \\
\text { generate and substantiate } \\
\text { ideas.." }\end{array}$ \\
\hline Linkage & $\begin{array}{l}\text { Close relationship with key } \\
\text { suppliers and partners. } \\
\text { "BTES works closely with our } \\
\text { key suppliers and partners to } \\
\text { be able to provide the most } \\
\text { reliable, safe and cost- } \\
\text { effective services in } \\
\text { implementing new innovations } \\
\text { through weekly conference } \\
\text { calls and meetings" }\end{array}$ & $\begin{array}{l}\text { Long term relationship with } \\
\text { key suppliers. } \\
\text { "Stellar has longstanding } \\
\text { relationships with these } \\
\text { providers and due to their } \\
\text { history of quality delivery } \\
\text { has confidence in their } \\
\text { ability to meet operational } \\
\text { needs." }\end{array}$ & $\begin{array}{l}\text { Nurturing relationship with } \\
\text { key customers. } \\
\text { "IPM relies on the personal } \\
\text { touch, with everyone in } \\
\text { Operations (Ops) } \\
\text { management, from the CEO } \\
\text { down, maintaining and } \\
\text { nurturing relationships with } \\
\text { key customer contacts..." }\end{array}$ \\
\hline Learning & $\begin{array}{l}\text { Review project to improve } \\
\text { performance. } \\
\text { "Employees are encouraged to } \\
\text { continuously look for ways for } \\
\text { BTES to improve, no matter } \\
\text { the size of the project." }\end{array}$ & $\begin{array}{l}\text { Training session focuses on } \\
\text { innovation. } \\
\text { "In 2016...the SLT added a } \\
\text { one-day training session } \\
\text { following New Employee } \\
\text { Orientation that focuses on } \\
\text { innovation." }\end{array}$ & $\begin{array}{l}\text { Training to deliver } \\
\text { innovative solutions for } \\
\text { customers. } \\
\text { "Job shadowing and } \\
\text { collaboration on projects } \\
\text { are used to teach new } \\
\text { consulting skills..." }\end{array}$ \\
\hline
\end{tabular}

Source: data processed 


\section{REFERENCES}

[1] R. Hodgetts, D. Kuratko, and J. Hornsby, "Quality Implementation in Small Business: Perspectives from the Baldrige Award Winners," SAM Adv. Manag. J., vol. 64, no. 1, p. 37, 1999.

[2] A. N. Prayudha and B. Harsanto, "Measuring service quality in Hotel X Bandung," ISTMET 2014 - 1st Int. Symp. Technol. Manag. Emerg. Technol. Proc., vol. 1, no. ISTMET, pp. 230-234, 2014, doi: 10.1109/ ISTMET.2014.6936511.

[3] P. Gopalakrishna and M. Chandra, "Malcolm Baldrige, Deming Prize and European Quality Awards: a review and synthesis," in Handbook of Total Quality Management, Springer, 1998, pp. 755-769.

[4] "About Baldrige | NIST." https://www.nist.gov/ baldrige/how-baldrige-works/about-baldrige (Accessed in Jan. 10, 2021).

[5] National Institute of Standards and Technology and United States Department of Commerce, "2019-2020 Baldrige Excellence Builder.” 2019, [Online]. Available: www.nist.gov/baldrige/publications.

[6] F. Damanpour, R. M. Walker, and C. N. Avellaneda, "Combinative Effects of Innovation Types and Organizational Performance: A Longitudinal Study of Service Organizations," J. Manag. Stud., vol. 46, no. 4, pp. 650-675, 2009.

[7] J. Birkinshaw, G. Hamel, and M. J. Mol, "Management innovation," Academy of Management Review, vol. 33, no. 4. pp. 825-845, 2008, DOI: 10. 5465/AMR.2008.34421969.

[8] W. H. Murphy and G. A. Wilson, "Dynamic capabilities and stakeholder theory explanation of superior performance among award-winning hospitals," Int. J. Healthc. Manag., vol. 0, no. 0, pp. 1-9, 2021, DOI: 10.1080/20479700.2020.1870356

[9] F. Damanpour and W. M. Evan, "Organizational Innovation and Performance: The Problem of " Organizational Lag "," Adm. Sci. Q., vol. 29, no. 3, pp. 392-409, 1984.

[10] F. Damanpour and D. Aravind, "Managerial Innovation: Conceptions, Processes, and Antecedents," Manag. Organ. Rev., vol. 8, no. 2, pp. 423-454, 2012, doi: 10.1111/j.1740-8784.2011.00233.x.

[11] J. M. Utterback, "The Process of Technological Innovation Within the Firm," Acad. Manag. J., vol. 14, no. 1 , pp. $75-88,1971$, doi: $10.5465 / 254712$.

[12] G. Azar and F. Ciabuschi, "Organizational innovation, technological innovation, and export performance: The effects of innovation radicalness and extensiveness," Int. Bus. Rev., vol. 26, no. 2, pp. 324 336, 2017, doi: 10.1016/j.ibusrev.2016.09.002.

[13] F. Damanpour, K. A. Szabat, and W. M. Evan, "The Relationship Between Types of Innovation and Organizational Performance," J. Manag. Stud., vol. 26, no. 6, pp. 587-601, 1989.

[14] J. Weerawardena, "Exploring the role of market learning capability in competitive strategy," Eur. J. Mark., vol. 37, no. 3/4, pp. 407-429, 2003, doi: 10.1108/03090560310459023.

[15] B. Harsanto, N. Kumar, Y. Zhan, and R. Michaelides, "Firms' ICT and Innovation in Jakarta Metropolitan Area," in 2020 International Conference on Technology and Entrepreneurship - Virtual, 2020, pp. $1-4$.

[16] T. S. Manolova and A. Yan, "Institutional constraints and entrepreneurial responses in a transforming economy: The case of Bulgaria," Int. Small Bus. J., vol. 20, no. 2, pp. 163-184, 2002.

[17] Y. Azis, M. R. Darun, D. Kartini, M. Bernik, and B. Harsanto, "A model of managing innovation of SMEs in Indonesia Creative Industries," Int. J. Bus. Soc., vol. 18, no. 35, pp. 391-408, 2017.

[18] M. I. Putri and B. Harsanto, "Value Chain Analysis in Small Business Context," in 2016 Global Conference on Business, Management and Entrepreneurship, 2016, pp. 309-313.

[19] B. Harsanto and H. Roelfsema, "Asian leadership styles, entrepreneurial firm orientation and business performance," Int. J. Entrep. Small Bus., vol. 26, no. 4, p. 490, 2015, doi: 10.1504/ijesb.2015.072759.

[20] S. Widianto and B. Harsanto, "The Impact of Transformational Leadership and Organizational Culture on Firm Performance in Indonesia SMEs," in The Palgrave Handbook of Leadership in Transforming Asia, N. Muenjohn and A. McMurray, Eds. London: Palgrave Macmillan UK, 2017, pp. 503-517.

[21] P. Wadhwa, M. McCormick, and M. Musteen, "Technological innovation among internationality active SMEs in the Czech economy: Role of human and social capital of CEO," Eur. Bus. Rev., vol. 29, no. 2, pp. 164180, 2017, doi: 10.1108/EBR-12-2015-0156. 
[22] S. Massa and S. Testa, "Innovation and SMEs: Misaligned perspectives and goals among entrepreneurs, academics, and policy makers," Technovation, vol. 28, no. 7, pp. 393-407, 2008, DOI: 10.1016/j.technovation. 2008.01.002.

[23] G. A. Bowen, "Document analysis as a qualitative research method," Qual. Res. J., vol. 9, no. 2, pp. 27-40, 2009, DOI: 10.3316/qrj0902027.

[24] J. Corbin and A. Strauss, "Strategies for qualitative data analysis," Basics Qual. Res. Tech. Proced. Dev. grounded theory, vol. 3, 2008.

[25] J. Tidd and J. Bessant, Managing Innovation: Integrating technological, market and organizational change. Chichester, UK: John Wiley \& Sons, Ltd, 2009.

[26] NIST, “Stellar Solutions Profile.” 2017, [Online]. Available:https://www.nist.gov/system/files/documents/ 2019/04/05/2018_memorial_hospital_baldrige_award_a pplication_summary.pdf.

[27] Bristol Tennessee Essential Services, “2017 Malcolm Baldrige National Quality Award Application Bristol Tennessee Essential Services.” 2017.

[28] NIST, "Bristol Tennessee Essential Services Profile." 2017, [Online]. Available: https:/www.nist. gov/system/files/documents/2019/04/05/2018_memoria 1_hospital_baldrige_award_application_summary.pdf.

[29] Integrated Project Management Company, “2018 Malcolm Baldrige National Quality Award Application Summary: IPM," no. 630, 2018, [Online]. Available: https://www.nist.gov/sites/default/files/documents/2017 /10/11/2011_Southcentral_Foundation_Award_Applica tion_Summary.pdf.

[30] NIST, "Integrated Project Management Company, Inc." 2018, [Online]. Available: https://www.nist. gov/baldrige/donor-alliance.

[31] Stellar Solutions, "2017 Malcolm Baldrige National Quality Award Application: Stellar Solutions.” 2017.

[32] B. Harsanto and C. T. Permana, "Sustainabilityoriented innovation ( SOI ) in the cultural village: an actor-network perspective in the case of Laweyan Batik Village," J. Cult. Herit. Manag. Sustain. Dev., 2020, doi: 10.1108/JCHMSD-08-2019-0102.

[33] B. Harsanto, R. Michaelides, and H. Drummond, "Sustainability-oriented Innovation (SOI) in Emerging Economies: A Preliminary Investigation from Indonesia," in 2018 IEEE International Conference on Industrial Engineering and Engineering Management
(IEEM), Dec. 2018, pp. 1553-1557, DOI: 10.1109/ IEEM.2018.8607473.

[34] G. Gumbira and B. Harsanto, "Decision Support System for An Eco-Friendly Integrated Coastal Zone Management ( ICZM ) in Indonesia," Int. J. Adv. Sci. Eng. Inf. Technol., vol. 9, no. 4, pp. 1177-1182, 2019.

[35] B. Harsanto, N. Kumar, Y. Zhan, and R. Michaelides, "Exploring Sustainability-Oriented Innovation Capabilities in the Indonesian Manufacturing Firms," Acad. Manag. Proc., vol. 2020, no. 1, p. 14242, Jul. 2020. 